\title{
PERCEIVED CRIMINALITY, CRIMINAL BACKGROUND CHECKS, AND THE RACIAL HIRING PRACTICES OF EMPLOYERS*
}

\author{
HARRY J. HOLZER, \\ Georgetown Public \\ Policy Institute
}

\author{
STEVEN RAPHAEL, \\ University of \\ California, Berkeley
}

and

MICHAEL A. STOLL

University of California, Los Angeles

\begin{abstract}
In this paper, we analyze the effect of employer-initiated criminal background checks on the likelihood that employers hire African Americans. We find that employers who check criminal backgrounds are more likely to hire African American workers, especially men. This effect is stronger among those employers who report an aversion to hiring those with criminal records than among those who do not. We also find similar effects of employer aversion to ex-offenders and their tendency to check backgrounds on their willingness to hire other stigmatized workers, such as those with gaps in their employment history. These results suggest that, in the absence of criminal background checks, some employers discriminate statistically against black men and/or those with weak employment records. Such discrimination appears to contribute substantially to observed employment and earnings gaps between white and black young men.
\end{abstract}

\section{INTRODUCTION}

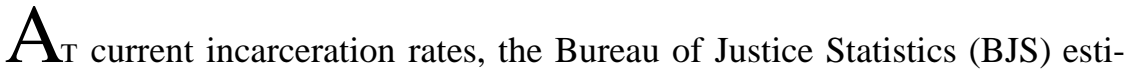
mates that approximately 9 percent of all men will serve time in state or federal prisons. These projections differ by race and ethnicity, with figures of 28 percent for black males, 16 percent for Hispanic males, and 4 percent for white males (Bonczar and Beck 1997). ${ }^{1}$ The BJS also estimates that the median time served for recent prison releases is less than 2 years. In combination, these two facts suggest that at any point in time a large minority of noninstitutionalized men have criminal history records. For certain sub-

* We thank the Russell Sage Foundation for their generous support of this project.

${ }^{1}$ We report figures for men only since they constitute the majority of prison inmates (over 90 percent).

[Journal of Law and Economics, vol. XLIX (October 2006)]

(C) 2006 by The University of Chicago. All rights reserved. 0022-2186/2006/4902-0017\$01.50 
groups of the population, African Americans in particular, the proportion with past criminal convictions is quite large.

The labor market prospects of ex-offenders are affected by whether employers have access to their criminal history records. Employers may be reluctant to hire job applicants with criminal histories for fear that such applicants may harm a customer or be more likely to steal. If employers can and do review criminal history records, they may use these records to exclude ex-offenders from consideration. Given the high proportion of blacks that have served time, such exclusion should have particularly adverse consequences for African Americans.

Whether employers review criminal history records may also impact the labor market prospects of individuals without criminal records. If accessibility to criminal history information is limited (because of cost or legal prohibitions), employers may infer the likelihood of past criminal activity from such traits as gender, race, or age. Such statistical discrimination would adversely affect the employment outcomes of individuals with clean histories who belong to demographic groups with high conviction rates. This negative effect should also disproportionately impact African Americans, although the segment of the black population affected by such discrimination is distinct from the segment excluded from opportunities because of criminal background checks.

These arguments suggest that the net effect of criminal background checks on the hiring of blacks is theoretically ambiguous. Employers who check will be more likely to eliminate black applicants on the basis of revealed information, while employers who do not may eliminate black applicants on the basis of perceived criminality. Moreover, it is unclear which of these effects should predominate. In this paper, we analyze the effect of employerinitiated criminal background checks on the hiring of African Americans. Using establishment-level data, we assess whether the race of the most recently hired employee is impacted by whether the employer screens criminal history records. We also assess whether the impact of criminal background checks varies with the intensity of the employer's aversion to workers with criminal histories.

We find that employers that check criminal backgrounds are in general more likely to hire African Americans. This holds for the likelihood of hiring black men as well as black women, although this result is stronger for black men. When we stratify the sample by employer self-reported willingness to hire ex-offenders, we find a strong positive effect of criminal background checks for employers that are averse to hiring ex-offenders. This effect is larger and statistically distinguishable from the comparable effect for employers with no such aversion. This relative pattern holds for the hiring of African Americans overall and for the hiring of black men, but not for the hiring of black women. Finally, in an analysis of employer willingness to hire other stigmatized groups of workers (such as workers with gaps in their 
employment history), we find nearly identical relationships. Combined, these results suggest that in the absence of background checks, employers use race, gaps in employment history, and other perceived correlates of criminal activity to assess the likelihood of an applicant's previous felony convictions and factor such assessments into the hiring decision.

\section{Criminal History Records and Black Hiring Outcomes}

\section{A. Employer Preferences and Access to Criminal Justice Information}

There are several reasons why employers may screen the criminal history records of potential employees. To start, certain occupations are closed to individuals with a felony conviction under state and in some cases federal law (Hahn 1991). In addition, in many states employers can be held liable for the criminal actions of their employees (Bushway 1998). ${ }^{2}$ Finally, employers who need to fill positions where employee monitoring is imperfect may place a premium on trustworthiness and may have little confidence in ex-offenders. ${ }^{3}$

There is strong evidence of employer aversion to applicants with criminal history records in the establishment data that we analyze. Figure 1 presents the distribution of employer responses to a question inquiring about the likelihood that the employer would be willing to accept an applicant with a criminal record. ${ }^{4}$ Over 60 percent of employers indicate an aversion to hiring ex-offenders. Moreover, Figure 2 reveals that this aversion is stronger on average than employer aversion to hiring other groups of commonly stigmatized workers, such as welfare recipients, applicants with a general equivalency diploma (GED), or applicants with gaps in their employment histories. Employers exhibit the most aversion to hiring applicants with spotty work histories (a characteristic that one might interpret as indirectly signaling past incarceration). Even for this group, however, the proportion willing to consider such applicants exceeds the proportion willing to consider ex-offenders.

\footnotetext{
${ }^{2}$ Scott (1987) cites several examples in which employers were held responsible for the criminal acts of their employees under the theory of negligent hiring, including judgments against the owner of a taxi company and a security services firm for sexual assaults committed by employees. In one cited instance involving a sexual assault committed by an apartment manager, the owner of an apartment complex was found negligent for not taking into account gaps in the manager's work history in the hiring decision.

${ }^{3}$ Whether the employer can legally consider such information in making hiring decisions is another matter. The Equal Employment Opportunities Commission guidelines prohibit "blanket exclusions" of applicants with criminal records. However, employers can consider criminal histories so long as the severity of the offense is related to the applicant's ability to effectively perform the job and so long as the employer considers the time lapsed since offending in coming to a decision (see Bushway 1998).

${ }^{4}$ The data were collected in the early 1990s and cover establishments in the Atlanta, Boston, Detroit, and Los Angeles metropolitan areas that hire workers without college degrees. The data source and sampling frame will be discussed in detail below.
} 


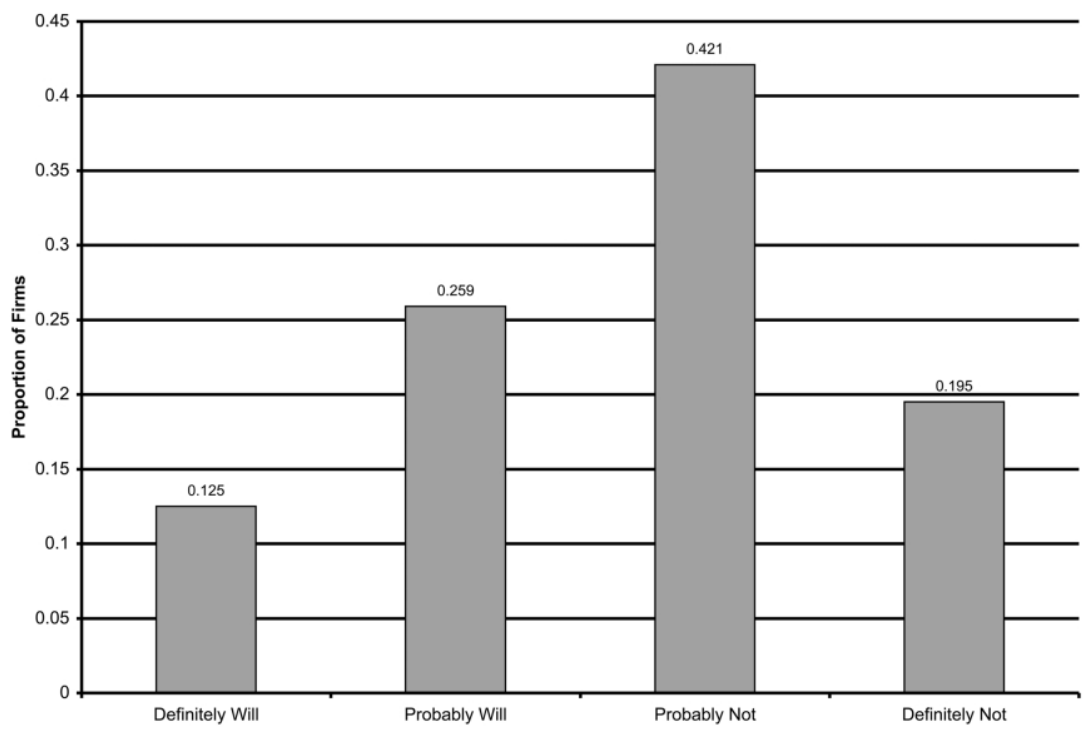

FIGURE 1.-Self-reported employer willingness to hire applicants with criminal records

Whether and how employers screen out ex-offenders depends on employers' access to criminal history record information. Criminal history records are obtained by querying central state repositories maintained by each state and the District of Columbia. State law enforcement agencies are required to report arrest and disposition information to the repository for all serious offenses. In a recent policy review, the U.S. Department of Justice (1999) concludes that criminal history records are increasingly becoming more available to noncriminal justice users. Currently, 23 states have some form of public access or freedom-of-information statutes pertaining to criminal history record information. ${ }^{5}$

In our data, a sizable fraction of employers use criminal background checks to screen potential employees, as Figure 3 demonstrates. Roughly half of employers either always or sometimes check the criminal history records of applicants. Moreover, for the one city for which we have data for two points in time (Los Angeles), employer use of such checks appears to have increased (see Figure 4). Hence, the noted trend toward greater accessibility to criminal history records is evident among employers in the Los Angeles metropolitan area.

\footnotetext{
${ }^{5}$ Nearly all states make a distinction between arrest records and conviction records. States are generally less likely to disseminate information on arrests and place fewer restrictions on non-criminal-justice access to conviction records.
} 


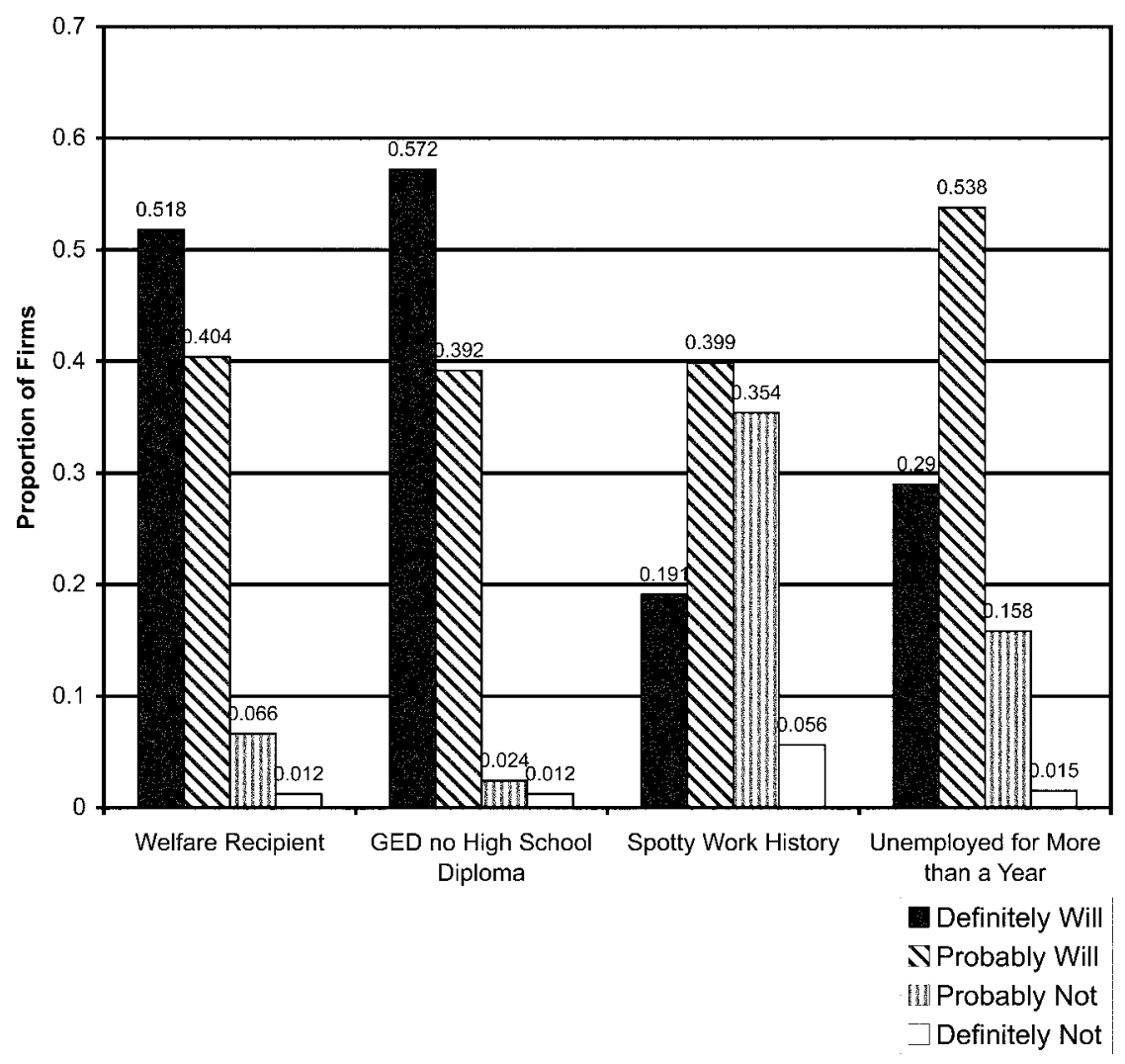

FIGURE 2.- Self-reported employer willingness to hire applicants from various disadvantaged (low-skilled) groups.

\section{B. The Availability of Criminal History Records and Employer Hiring Decisions}

The effect of background checks on black employment outcomes depends on how employers make use of such information. Employers may view the potentially lower productivity of ex-offenders as a payroll tax that reduces marginal product. Such employers may offer ex-offenders employment, but at reduced wages. Alternatively, employers may perceive the downside of employing ex-offenders as so large that marginal wage reductions would not constitute sufficient compensation. Such employers will avoid hiring exoffenders all together. Given the aversion to ex-offenders documented above, such a quantity response is the more likely margin of adjustment. On the basis of this reasoning, this paper focuses on the hiring decision.

To illustrate the theoretically ambiguous effect of criminal background 


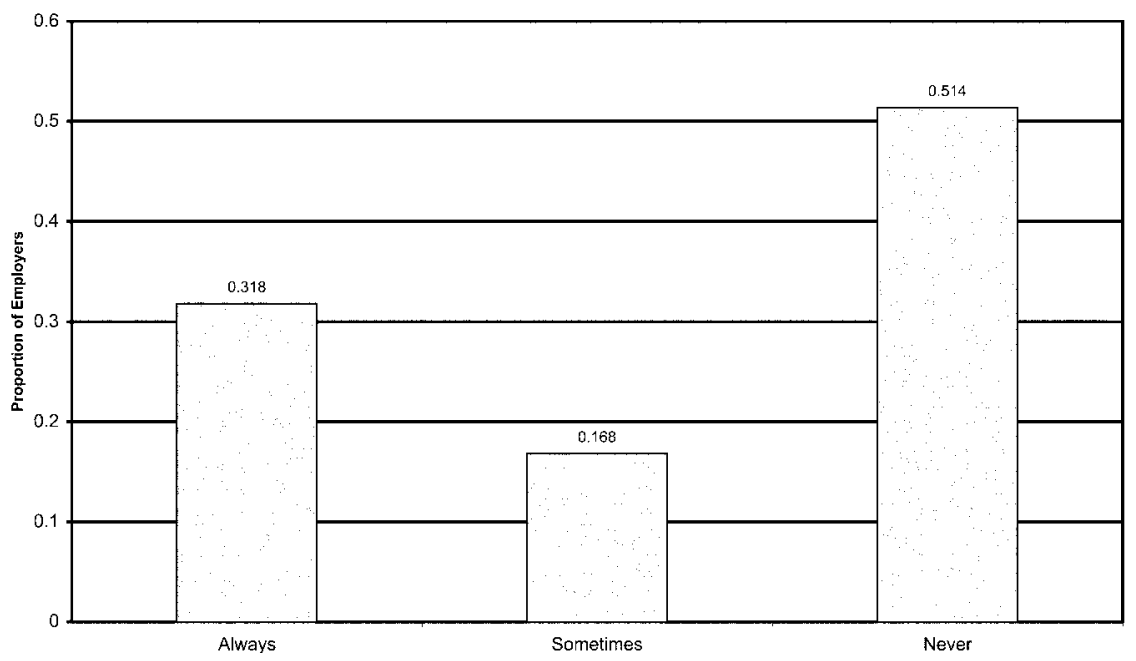

FIGURE 3.-Frequency with which employers check criminal backgrounds

checks on the likelihood of hiring an African American applicant, we employ a simplified version of the statistical discrimination model presented by Altonji and Pierret (2001). Let $v_{i}$ be the productivity of a job applicant $i$, which is determined by the equation

$$
v_{i}=\beta_{0}+\beta_{1} S_{i}+\beta_{2} C_{i}+\beta_{3} B_{i}+\eta_{i},
$$

where $S_{i}$ is educational attainment, $C_{i}$ is a measure of criminality, $B_{i}$ is an indicator variable for black, $\eta_{i}$ is a mean-zero random error term, and $\beta_{0}$ through $\beta_{3}$ are parameters. Assume that employers hire applicants with positive productivity (that is, $v_{i}>0$ ) and that criminality negatively affects productivity $\left(\beta_{2}<0\right)$. Criminality is determined by the equation

$$
C_{i}=\alpha_{0}+\alpha_{1} S_{i}+\alpha_{2} B_{i}+\varepsilon_{i}
$$

where $\alpha_{0}$ through $\alpha_{2}$ are parameters, $\varepsilon_{i}$ is a mean-zero random disturbance, and all other variables are as defined. The parameter $\alpha_{2}$ provides the mean difference in criminality between blacks and nonblacks that is assumed to be positive.

We begin with the case in which employers have full access to criminal history records. The difference between the probabilities of hiring a nonblack and a black applicant chosen at random will be an increasing function of the average productivity difference between the two groups. This follows from 


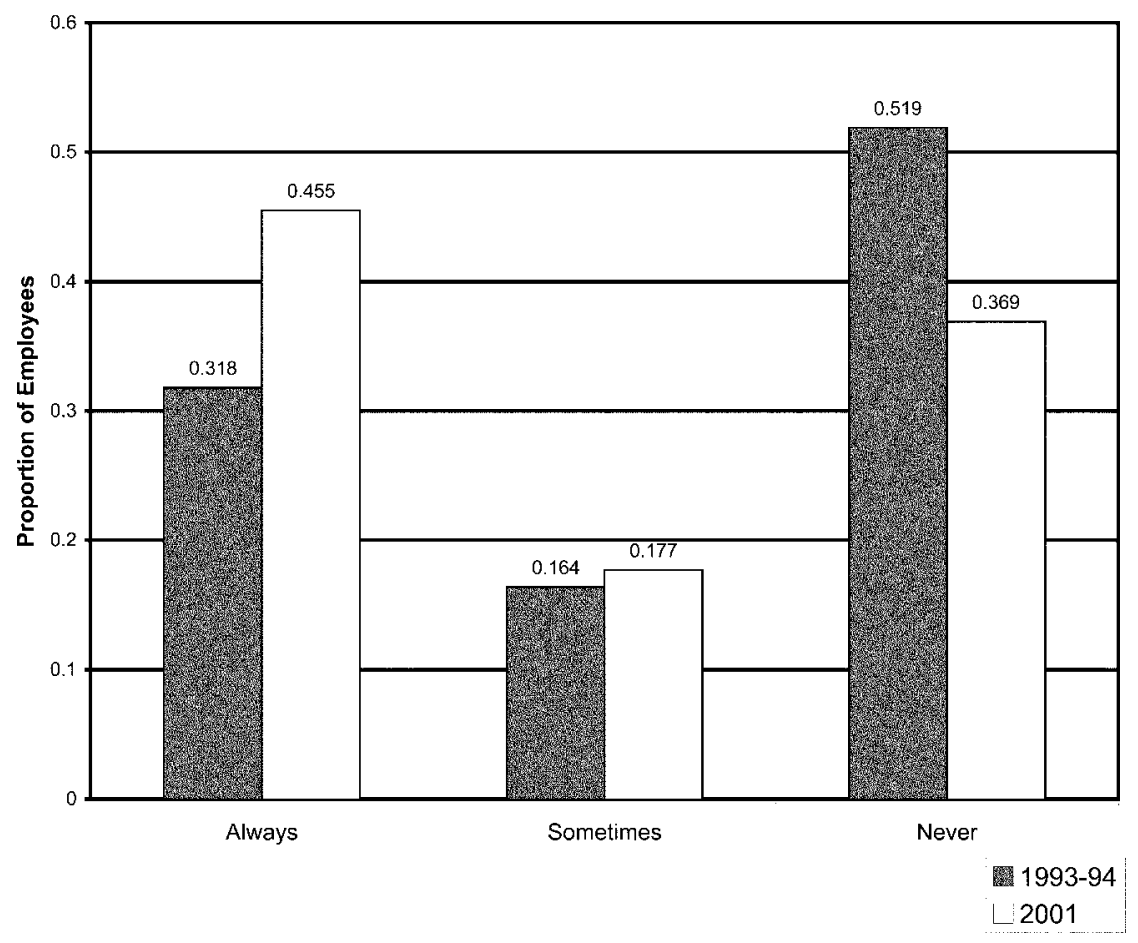

FIGURE 4.-Frequency with which employers check criminal backgrounds in Los Angeles, 1993-94 and 2001.

the employer's hiring rule. The difference in the expected value of productivity is given by

$$
\begin{gathered}
E\left(v_{i} \mid S, B=0\right)-E\left(v_{i} \mid S, B=1\right) \\
=-\beta_{3}+\beta_{2}[E(C \mid S, B=0)-E(C \mid S, B=1)] .
\end{gathered}
$$

After substituting the racial difference in criminality for the last term on the right, the difference in expected productivity can be rewritten as

$$
E\left(v_{i} \mid S, B=0\right)-E\left(v_{i} \mid S, B=1\right)=-\beta_{3}-\beta_{2} \alpha_{2} .
$$

The portion of this mean productivity difference associated with differential criminality lowers the relative likelihood that the firm hires black workers. Note, in this instance, that employers observe the true value of $C_{i}$, a fact that on average harms black employment prospects.

Now suppose that employers cannot review criminal history records. One possibility is that employers ignore equation (2) and make hiring decisions that are based only on the direct effects of schooling and race on productivity. 
This would involve ignoring the relationship between race and criminality and would eliminate the expected difference in productivity between black and nonblack job applicants operating through this factor. If this were an accurate description of employer behavior, then limiting access to criminal history records would unambiguously increase the relative hiring rates of African American applicants.

An alternative possibility is that employers formulate expectations concerning the relationship between race and criminality and take these expectations into account. One manner of modeling the process by which employers "estimate" the criminality of job applicants is to assume that employers know the parameters of the criminality equation (2). Such an estimate might be considered rational in the sense that employers do not systematically underestimate the criminality of minorities (as in the previous example) or overestimate the relationship (as discussed below). Under these assumption, employers estimate criminality on the basis of schooling and race according to the equation

$$
E(C \mid S, B)=\alpha_{0}+\alpha_{1} S_{i}+\alpha_{2} B_{i} .
$$

Substituting this conditional expectation into equation (1), an employer's estimate of a given applicant's productivity in the absence of perfect information is given by

$$
E(v \mid S, B)=\beta_{0}+\beta_{2} \alpha_{0}+\left(\beta_{1}+\beta_{2} \alpha_{1}\right) S_{i}+\left(\beta_{3}+\beta_{2} \alpha_{2}\right) B_{i} .
$$

Since the employer cannot observe criminality in this scenario, the employer places extra weight on the correlates of criminality (race and schooling, in this example) in formulating expectations about the likely productivity of the job applicant.

In this instance, the difference between the likelihood of hiring a nonblack applicant and the likelihood of hiring a black applicant will again be an increasing function of the difference in the expected productivity between the two groups, or

$$
E\left(v_{i} \mid S, B=0\right)-E\left(v_{i} \mid S, B=1\right)=-\beta_{3}-\beta_{2} \alpha_{2},
$$

which is equivalent to the expected productivity differential when criminal history records are perfectly accessible. Hence, if employers accurately estimate the relationship between race and criminality, increasing access to criminal history records will not affect the relative hiring rates of blacks. ${ }^{6}$

Of course, this result depends critically on the assumption that employers accurately estimate the relationship between criminality and race. If employers systematically overestimate the racial difference in criminality, then

\footnotetext{
${ }^{6}$ Of course, the composition of the pools of who is hired and who is not will change. Statistical discrimination will clearly harm some applicants with positive productivity while benefiting others with negative productivity.
} 
the expected productivity difference in equation (7) will be larger than the actual difference. Here, increasing employer access to criminal history records would actually increase the likelihood that employers hire black applicants.

Statistical discrimination models commonly assume that the pursuit of profits will eventually align expectations and reality (Aigner and Cain 1977; Lundberg and Startz 1983). Employers who consistently under- or overestimate the relationship between a signal and an unobservable factor that affects productivity will suffer as a consequence. In the example analyzed here, however, the underlying relationship that employers would need to assess has changed considerably over the past 2 decades. Moreover, the sharp increase in prison incarceration rates among young black males may easily lead to a period of overestimated criminality that only time and experience will undo. ${ }^{7}$ Regardless, the model illustrates how the net effect of increasing or restricting access to criminal history records on the hiring rates of African Americans is an empirical issue.

While there is little research on the effects of criminal background checks on minority hiring, several studies address related questions. Bushway (1998, 2004) hypothesizes that restricted access to state repositories is likely to lower the relative wages of blacks because of statistical discrimination. In earlier work, Bushway (1998) assesses whether the black/white wage ratio is lower in states where the criminal history record systems are automated, where automation serves as a proxy for greater accessibility. In the later work, Bushway (2004) estimates the effect on the black/white wage ratio of the degree of openness of state repositories to non-criminal-justice users. Both studies yield evidence that the black/white wage ratio is higher in states with lower barriers to access, although the results are not always significant.

Autor and Scarborough (2004) find that formal screening devices do not reduce the hiring of blacks, despite the relatively poor performance of black applicants on standardized assessments. While that study does not address criminal background checks, the results parallel the argument made here. The authors analyze hiring outcomes at a large national retail chain that introduced formal test-based applicant assessment procedures. The relatively low black test scores coupled with the strong effect of scores on the likelihood of being hired yield the prediction that introducing the formal screening would reduce black hiring rates by nearly 20 percent. However, the authors find no such reduction, suggesting that the subjective assessments of black applicants by interviewers prior to testing negatively impacted black hiring rates.

Finally, a recent audit study by Pager (2003) provides further evidence

\footnotetext{
${ }^{7}$ Moreover, it is not particularly clear that time and experience will undo employer misperceptions. In fact, the response of black job applicants to such misperceptions could potentially create a negative feedback loop whereby erroneous employer beliefs are eventually correct. For a thorough discussion of such processes, see Loury (2002).
} 
consistent with our model. Pager conducted an audit study in Milwaukee whereby pairs of auditors of the same race were sent to apply for the same jobs, one with a spell in prison listed on his resume and one with no such signal. Among the white auditors, 34 percent of the nonoffenders received a callback in contrast to 17 percent of ex-offenders. The comparable figures for blacks were 14 and 5 percent. Consequently, Pager draws two conclusions. First, the ex-offender stigma effect is larger for blacks (given the 65 percent reduction in the callback rates for black ex-offenders relative to the 50 percent reduction for whites). ${ }^{8}$ Second, animus-based racial discrimination against blacks is more important in explaining the inferior employment outcomes of black men (given the finding that black nonoffenders receive fewer callbacks than white ex-offenders).

Our theoretical argument provides an alternative interpretation of the low callback rate for black nonoffenders. In Pager's study, the auditor marked as an ex-offender explicitly signals having been in prison by including inprison work experience on his resume. The nonoffending auditor does not reveal a criminal past. If employers believe that all young black men have served time, the low callback rate for black nonoffenders may reflect statistical discrimination. ${ }^{9}$ Moreover, as noted by Bushway (2004), the audited sample of job openings explicitly excludes job openings for which a background check is likely (for example, jobs that are legally closed to exoffenders and job advertisements with explicit mentions of background checks). Moreover, the majority of employers audited care enough about the criminal backgrounds of the applicants to inquire about it on their application forms. As our empirical work below will demonstrate, employers that are averse to hiring ex-offenders and that do not check are the most likely to engage in statistical discrimination.

\section{Empirical Strategy and Description of the Data}

The theoretical discussion indicates that the impact of employer access to criminal history records on black hiring rates depends on the extent to which employers statistically discriminate in the absence of such information. Moreover, the accuracy with which employers estimate the relationship between race and criminality will impact the net effect of criminal background checks. Since this net effect is theoretically ambiguous, this question is inherently

\footnotetext{
${ }^{8}$ However, the percentage point decline in the callback rate for white offenders (17 points) exceeds the percentage point decline for black offenders ( 9 points).

${ }^{9}$ One possible test of this hypothesis would be to assess whether there is an order effect on the likelihood that the black nonoffender auditor received a callback. Specifically, in instances when the ex-offender applies first, the appearance of the prison information on the auditor's resume may prime a cognitive association between race and crime in the mind of the employer. To the extent that this triggers the subjective assessment of the employer, one should observe a lower callback rate for the nonoffender black auditor in audits when he is the second to apply.
} 
empirical. In this section, we outline a strategy for assessing the consequences of employer-initiated criminal background checks on firm hiring outcomes.

We estimate the effect of criminal background checks on the likelihood that an employer's most recent hire is African American. Using a sample of establishments, we estimate a series of linear probability models in which the dependent variable is a dummy variable that indicates that the most recent hire is black and the key explanatory variable is an indicator variable set to one if the employer uses criminal background checks in screening applicants for the recently filled position.

The principal identification problem encountered concerns the possibility that use of criminal background checks is likely to reflect the characteristics of a firm's applicant pool. For example, employers that face a disproportionately black applicant pool and that wish to screen out ex-offenders will be both more likely to check criminal backgrounds as well as more likely to hire African Americans. We address this identification problem with a two-pronged strategy. First, we attempt to include extensive control for factors that are likely to influence the composition of the applicant pool. Second, we test for a differential effect of checking criminal backgrounds by the degree of self-reported employer aversion to hiring ex-offenders. Finally, we test for an effect of background checks on employer willingness to hire other stigmatized job applicants.

There is considerable evidence suggesting that certain employers draw quite heavily on minority labor supplies. For example, there is ample evidence that demonstrates that black-owned businesses and establishments with African American management are considerably more likely to hire black workers (Bates 1993; Turner 1997; Carrington and Troske 1998; Raphael, Stoll, and Holzer 2000). Moreover, several studies show that urban space racially segregates racial employment and search distributions. ${ }^{10}$ Hence, one might contend that variation in whether employers check criminal history records would occur along such dimensions. Omitting the composition of the applicant pool from the analysis would thus create a spurious positive correlation between employer use of criminal background checks and the likelihood of hiring black workers.

Our first strategy for addressing this identification problem is to control extensively for characteristics of the establishment that are likely to impact the racial composition of the firm's labor supply. Specifically, in our models of firm hiring outcomes we include extensive controls for the firm's spatial proximity to black and white residential communities. In addition, we control directly for employer self-reports concerning the proportion of the applicant

\footnotetext{
${ }^{10}$ Holzer (1996), Ihlanfeldt and Young (1996), and Raphael, Stoll, and Holzer (2000) all show large geographic differences in the likelihood that employers hire African Americans. Stoll and Raphael (2000) show that black and white workers search for jobs in different areas of the metropolitan area, with much of the difference explained by racial housing segregation.
} 


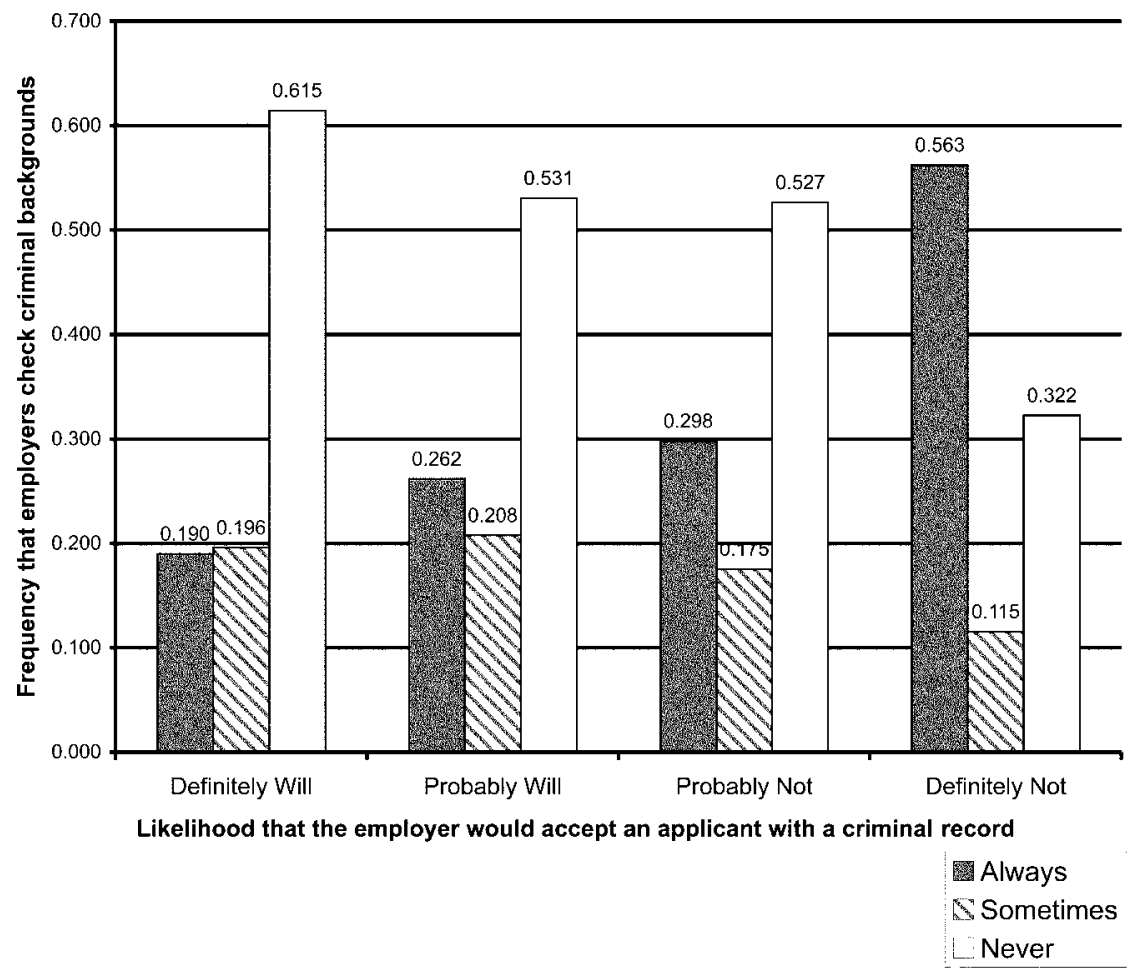

FIGURE 5.-Frequency of criminal history record checks by employer willingness to hire applicants with criminal records

pool that is black. Finally, we make use of the extensive information on employer skill needs and screening methods collected in the survey to adjust the estimates for interestablishment variation in the demands placed on new employees.

Our second strategy exploits the imperfect association between whether employers check criminal backgrounds and the employers' self-reported aversion to hiring workers with criminal histories. Figure 5 graphically presents employers' reported use of criminal background checks by employer willingness to hire applicants with criminal records. There is a strong association between unwillingness to hire and the use of criminal background checks, although this correlation is far from perfect.

Variation in the use of this screening device within these subsamples permits a more precise assessment of the likely impacts of increasing employer access to criminal history records. One might hypothesize that employers with a strong stated aversion to hiring applicants with criminal history records are more likely to statistically discriminate in the absence of a formal 
criminal background check. Moreover, if there is a systematic tendency of employers to overestimate the strength of the relationship between race and criminality, one might expect that employers least willing to hire ex-offenders (perhaps the employers with the most to lose if they make a false-negative inference) will be the most likely to commit such an error. These arguments suggest that the net effect of employer-initiated background checks will be heterogeneous, with more positive effects for those employers least willing to hire ex-offenders. In other words, there should be a positive interaction effect between criminal background checks and employer unwillingness to hire. ${ }^{11}$

We employ this strategy in an attempt to detect statistical discrimination aimed at weeding out applicants with criminal records. We first stratify the sample into two groups defined by employer unwillingness to hire exoffenders. Next we calculate within-group difference in the likelihood of hiring black applicants between employers who check and employers who do not. We then test whether the effect of background checks is larger for the least willing employers by calculating the relevant difference in difference and testing its significance. We present difference-in-difference estimates that are both unadjusted and regression adjusted for observable variables.

We use an establishment survey collected through the Multi-city Study of Urban Inequality (Holzer et al. 2000). The survey includes slightly over 3,000 establishments and was conducted between June 1992 and May 1994 in the Atlanta, Boston, Detroit, and Los Angeles metropolitan areas. The sample of firms is drawn from two sources: from the employers of the respondents to a household survey conducted in conjunction with the survey of establishments that provided approximately 30 percent of the observations and from a sample of establishments generated by Survey Sampling Incorporated (SSI). The SSI sample is a random-stratified sample in which the initial lists are stratified by establishment size and firms are sampled according to the proportion of metropolitan area employment accounted for by their size categories. Hence, the SSI sample is representative of the set of establishments faced by a job seeker in any of the four metropolitan areas. We use sample weights in all calculations and model estimations to account for the nonrepresentative portion of the sample from the household survey. Establishments were screened according to whether they had hired an employee into a position not requiring a college degree within the previous year. The

\footnotetext{
${ }^{11}$ This idea is conceptually similar to the estimation strategy employed by Holzer and Ihlanfeldt (1998) in their assessment of the importance of customer discrimination in determining the race of recent hires. The authors reason that the effect of customer discrimination on the likelihood that blacks are hired should matter most for positions involving direct customer contact. On the basis of this proposition, they test for an interaction effect between a dummy indicating a customer contact job and the racial composition of the establishment's customers in regression models where the dependent variable is a dummy indicating that the most recent hire is black.
} 
TABLE 1

Conditional Averages of Hiring Outcomes

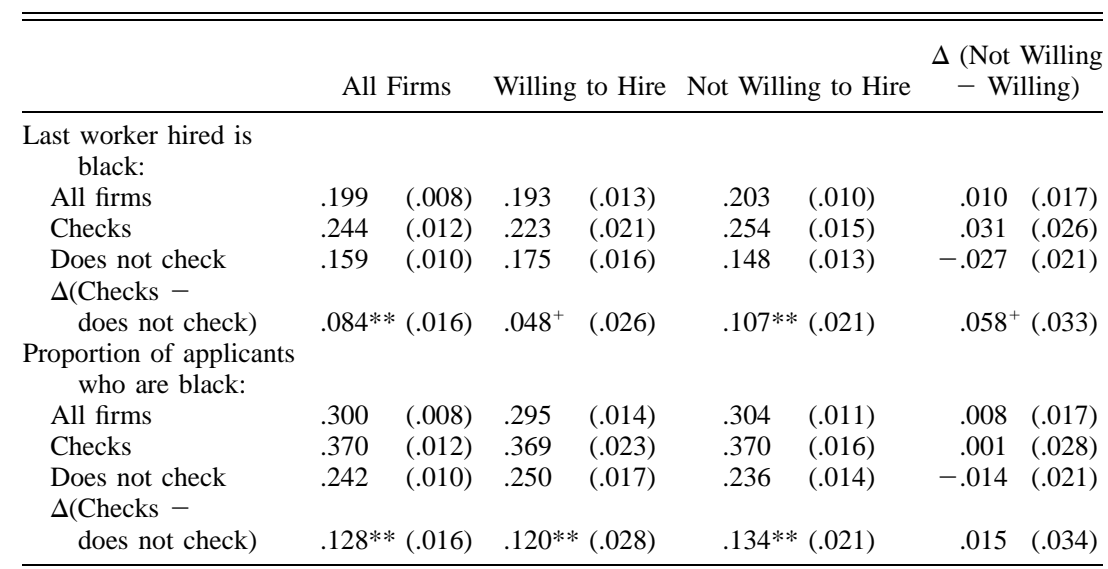

NoTE. - Standard errors are in parentheses. Firms that always check or sometimes check criminal backgrounds are coded as checking. Firms that state that they "definitely will" or "probably will" hire a worker with a criminal background are coded as willing to hire, while firms stating "probably not" or "absolutely not" are coded as unwilling to hire.

${ }^{+}$Difference significant at the $10 \%$ level of confidence.

** Difference significant at the $1 \%$ level of confidence.

response rate for firms that passed the initial screen is 67 percent. This compares favorably with other establishment surveys (Kling 1995). ${ }^{12}$

Telephone surveys were conducted with individuals in charge of hiring at the firm. Our chief dependent variable is the race of the most recent hire into a position not requiring a college degree. The survey includes two questions vital to the current analysis: a question on employer preferences with respect to workers with criminal histories and a question on whether employers use criminal background checks. ${ }^{13}$ These three variables provide our key dependent and explanatory variables for the analysis below.

\section{EMPIRICAL Results}

Table 1 presents average values for a dummy variable indicating that the last worker hired is black and for the proportion of applicants to the establishment that are African Americans. There is no overall difference in the likelihood of hiring a black worker between unwilling and willing employers. There is a large significant difference, however, between employers that do

\footnotetext{
${ }^{12}$ Holzer (1996) provides detailed comparisons of response rates by industry, location, and establishment size and finds no substantial differences in response rates.

${ }^{13}$ For criminal background checks, the question reads, "For the last position hired into, how often do you check the applicant's criminal records? always, sometimes, or never?" The question on employer preferences reads, "Would you accept for this position an applicant who had a criminal record? definitely will, probably will, probably not, absolutely not?"
} 
background checks and employers that do not. Employers that check are 8.4 percentage points more likely to have hired an African American applicant into the most recently filled position. Among employers willing to hire exoffenders, this difference is 4.8 percentage points and is marginally significant. Among employers who are unwilling to hire ex-offenders, this difference is 10.7 percentage points and is highly significant. Moreover, the difference between these two differences (5.8 percentage points) is significant at the 8 percent level.

The patterns for proportions of black applicants, however, indicate that these findings may be driven by differences in the application rates of blacks across establishments. The percent of applicants who are African American at firms that check is nearly 13 percentage points greater than the comparable percent at establishments that do not. While this may reflect a response on the part of black applicants (black applicants apply where they are most likely to be hired), the strong association between the racial composition of the applicant pool and checking qualifies the interpretation of the patterns for the race of the last worker hired. However, we do not find the same relative patterns when the sample is stratified by willingness to hire. While the point estimate for unwilling firms is slightly higher, the relative difference is small and only half the size of its standard error.

One might suspect that background checks should be more likely to impact the hiring outcomes of black men than those of black women. While black women are incarcerated at a relatively high rate, the population of incarcerated African Americans is overwhelmingly male (over 90 percent). To explore potential gender differences, Table 2 reproduces the conditional averages presented in Table 1 using gender-specific outcome variables.

Relative to unwilling employers, willing employers are more likely to have recently hired a black male (2.1 percentage point difference, significant at the 10 percent level), as are employers that check relative to those that do not (3.6 percentage points, significant at the 1 percent level). When establishments are stratified by preferences, we see a large, significant, and positive impact of checking on the hiring of black males (5.6 percentage points, significant at the 1 percent level) among unwilling employers and a negligible and insignificant effect of checking among willing employers. Consequently, the relative impact of checking criminal backgrounds for unwilling firms relative to willing firms (the difference-in-difference estimate) is positive (4.4 percentage points) and significant at the 10 percent level.

The results for the black female hiring outcome yield some interesting differences. While we still observe an overall positive and significant difference between employers that check and employers that do not (4.8 percentage points), unwilling employers are more likely to have recently hired a black woman than willing employers ( 3 percentage point difference, significant at the 5 percent level). This contrasts with an overall negative effect of employer aversion on the likelihood of hiring a black man. Stratifying the 
TABLE 2

Racial and Gender Composition of the Last Worker Hired

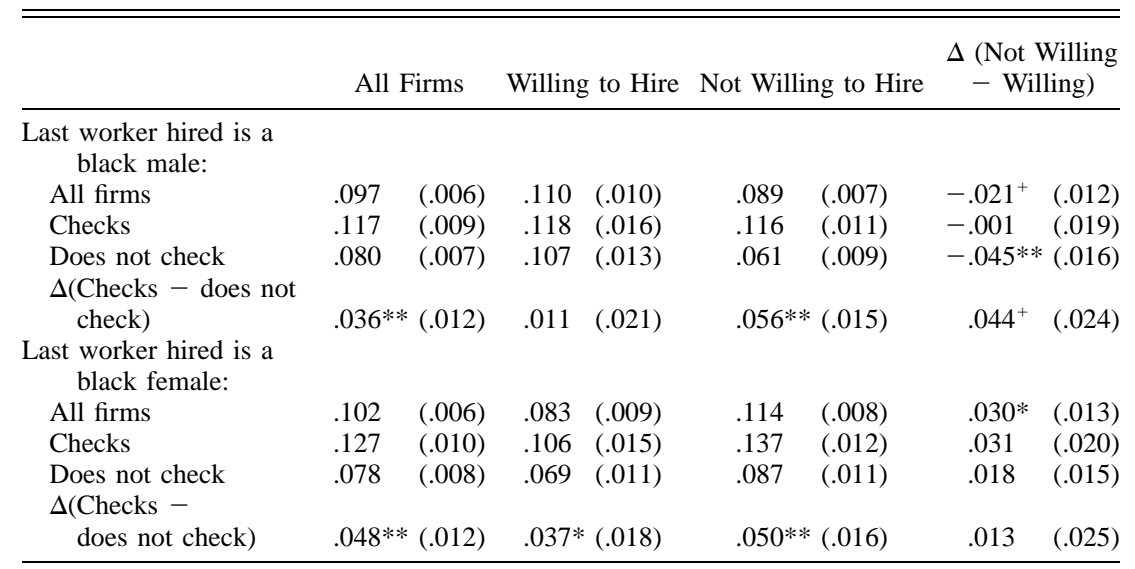

NotE. - Standard errors are in parentheses. Firms that always check or sometimes check criminal backgrounds are coded as checking. Firms that state that they "definitely will" or "probably will" hire a worker with a criminal background are coded as willing to hire, while firms stating "probably not" or "absolutely not" are coded as unwilling to hire.

${ }^{+}$Difference significant at the $10 \%$ level of confidence.

* Difference significant at the $5 \%$ level of confidence.

** Difference significant at the $1 \%$ level of confidence.

sample by willingness to hire ex-offenders, the checking/nonchecking differentials are comparable for willing employers (3.7 percentage points) and unwilling employers ( 5 percentage points), with an insignificant differencein-difference result.

To be sure, the patterns observed in Tables 1 and 2 may be driven by factors correlated with checking criminal backgrounds, employer aversion to ex-offenders, and the interaction between the two. Fortunately, we are able to observe several establishment characteristics. Tables A1 and A2 present means of observable variables for the sample stratified by employer aversion to hiring ex-offenders (Table A1) and by employer use of criminal background checks in screening applicants (Table A2). These tables do indeed reveal several noticeable differences across establishments. For example, smaller, nonmanufacturing firms whose employees interact with customers are the most averse to hiring ex-offenders. In addition, averse employers are less likely to use informal recruiting techniques (walk-ins, for example) and are less likely to hire workers with gaps in their employment history. Table A2 reveals that small employers are least likely to use criminal backgrounds checks, as are employers in the manufacturing sector. Moreover, employers that check criminal backgrounds are more likely to use informal recruiting methods (accepting walk-ins and posting help-wanted signs), are more likely to accept referrals from state and community agencies, and are more likely to use affirmative action in recruiting. 
To probe the robustness of the results in Tables 1 and 2, Table 3 presents regression-adjusted estimates of the impact of criminal background checks after adjusting for the observable variables listed in the Appendix tables. The table presents the results from two underlying empirical models. The first regresses a dummy variable indicating that the most recent hire is black on the dummy indicating that the employer checks criminal backgrounds. The second adds whether the employer indicates an unwillingness to hire exoffenders and an interaction term between unwillingness to hire and background checking. Concerning the remaining covariates, the table presents results from four specifications. Specification (1) omits all other controls and thus corresponds to the differences in means presented in Table 1. Specification (2) add three metropolitan area dummies, a variable measuring the physical distance of the establishment's location from blacks ${ }^{14}$ and whites, and six interaction terms between the three metropolitan area dummies and the two distance dummies. Specification (3) adds the proportion of applications who are African Americans. Finally, specification (4) adds all of the other covariates in Tables A1 and A2. ${ }^{15}$

We begin with the results omitting the interaction term between background checks and employer preferences. Adding the distance, metropolitan area, and unwilling-to-hire variables causes a decline in the coefficient on criminal background checks from .085 to .043 . Nonetheless, the effect is statistically significant at the 1 percent level. Adding the proportion of applications from blacks causes a slight decline in the point estimate to .039 (significant at the 3 percent level of confidence). Adding all of the other control variables in regression 4 eliminates the effect of background checks on the likelihood that the most recently hired employee is black. Sensitivity analysis revealed that the variables that are particularly important in knocking out the effect include the dummies for firm size and industry and the variables indicating the types of employees that the employer will not consider.

Turning to the results including the interaction term, the effect of criminal background checks for willing employers is given by the coefficient on the criminal background checks variable. The effect for unwilling employers is given by the sum of the coefficients on the background checks variable and the interaction term. Thus, the interaction term coefficient measures the dif-

\footnotetext{
${ }^{14}$ The average distance from blacks is calculated using linear distances (in miles) between the centroid of the employer's census tract and the centroids of all other census tracts in the area. The variable for each employer is the weighted average of distance to all other census tracts where the weights are the black population counts in the destination tract. See Holzer and Ihlanfeldt (1996) and Raphael, Stoll, and Holzer (2000) for a more detailed discussion of these indexes.

${ }^{15}$ The sample size changes across regression specifications because several of the observations have missing values for one or more of the added explanatory variables. We also estimated separate models constraining the sample to observations with complete information on all explanatory variables. These results are qualitatively similar to those presented here.
} 
TABLE 3

Linear Regressions Models of the Likelihood That the Most Recent Hire Is Black

\begin{tabular}{|c|c|c|c|c|c|c|c|c|}
\hline & \multicolumn{2}{|c|}{$\begin{array}{l}\text { SPECIFICATION } 1 \\
\quad(N=2,441)\end{array}$} & \multicolumn{2}{|c|}{$\begin{array}{c}\text { SPECIFICATION } 2 \\
\quad(N=2,212)\end{array}$} & \multicolumn{2}{|c|}{$\begin{array}{l}\text { SPECIFICATION } 3 \\
\quad(N=1,505)\end{array}$} & \multicolumn{2}{|c|}{$\begin{array}{l}\text { SPECIFICATION } 4 \\
\quad(N=1,210)\end{array}$} \\
\hline & (1) & (2) & (1) & (2) & (1) & (2) & (1) & (2) \\
\hline Checks criminal backgrounds & $\begin{array}{c}.085 \\
(.016)\end{array}$ & $\begin{array}{c}.048 \\
(.026)\end{array}$ & $\begin{array}{c}.043 \\
(.016)\end{array}$ & $\begin{array}{c}.008 \\
(.027)\end{array}$ & $\begin{array}{c}.039 \\
(.018)\end{array}$ & $\begin{array}{c}.005 \\
(.030)\end{array}$ & $\begin{array}{c}-.015 \\
(.022)\end{array}$ & $\begin{array}{r}-.059 \\
(.033)\end{array}$ \\
\hline Unwilling to hire ex-offenders & & $\begin{array}{c}-.027 \\
(.022)\end{array}$ & $\begin{array}{c}-.001 \\
(.016)\end{array}$ & $\begin{array}{c}-.027 \\
(.023)\end{array}$ & $\begin{array}{c}-.008 \\
(.018)\end{array}$ & $\begin{array}{c}-.037 \\
(.025)\end{array}$ & $\begin{array}{c}-.008 \\
(.021)\end{array}$ & $\begin{array}{c}-.041 \\
(.028)\end{array}$ \\
\hline Checks $\times$ unwilling & & $\begin{array}{l}.058 \\
(.033)\end{array}$ & & $\begin{array}{l}.057 \\
(.033)\end{array}$ & & $\begin{array}{c}.052 \\
(.037)\end{array}$ & & $\begin{array}{l}.074 \\
(.041)\end{array}$ \\
\hline Spatial proximity to blacks ${ }^{a}$ & No & No & Yes & Yes & Yes & Yes & Yes & Yes \\
\hline Percent of black applicants & No & No & No & No & Yes & Yes & Yes & Yes \\
\hline Other covariates $^{\mathrm{b}}$ & No & No & No & No & No & No & Yes & Yes \\
\hline$R^{2}$ & .011 & .012 & .124 & .125 & .312 & .313 & .367 & .367 \\
\hline
\end{tabular}

NoTE. - All regression include a constant. Standard errors are in parentheses.

a These controls include a measure of the establishment's average distance to white neighborhoods, average distance to black neighborhoods, four metropolitan area dummies, and a complete set of interaction terms between the metropolitan area dummies and the distance variables.

${ }^{b}$ These controls include all of the covariates in Tables A1 and A2. 
ference in the effect of checking between employers that are unwilling and employers that are willing.

The results omitting all other controls (specification [1]) reproduce the patterns observed in Table 1. There are significant effects of checking criminal backgrounds on black hiring for both willing and unwilling employers. The larger effect for unwilling employers is statistically distinguishable from the effect for willing employers. Adding the distance variables and the metropolitan area dummies eliminates the base effect of criminal background checks for willing employers and reduces the effect for unwilling employers. The relative difference, however, is unaffected and remains significant at the 10 percent level of confidence. Directly controlling for the applicant pool racial composition does not affect the base coefficient on the background checks dummy and slightly diminishes the coefficient on the interaction term (which is now statistically insignificant, with a $p$-value of .166). Finally, adding all covariates causes a large decline in the base effect of background checks (the coefficient is -.059 , with a $p$-value of .076) and slightly increases the coefficient on the interaction term (which is again significant at the 7 percent level of confidence). The results in the final regression indicate that among willing firms, employer access to criminal history records decreases the likelihood of hiring African Americans. On the other hand, among unwilling employers, performing background checks leads to a slight increase in the likelihood of hiring African Americans.

Table 4 presents comparable results for the gender-specific hiring outcomes analyzed in Table 2. The model specifications parallel those used in Table 3. For each specification and each outcome, we present the results from two regressions: a regression excluding the interaction term between checking and employer unwillingness to hire ex-offenders and a regression including the interaction term.

Beginning with results for males, the models omitting the interaction term indicate a positive overall effect of checking criminal backgrounds on the hiring of black males. These effects are marginally significant in specifications (1)-(3) and insignificant in specification (4). Moreover, in all of the models excluding the interaction terms, employer aversion to hiring exoffenders has a negative and significant effect on the likelihood of hiring black males. In the models including the interaction term, the point estimate consistently indicates that checking has a larger effect on the likelihood of hiring black men for unwilling firms relative to willing firms. This effect, however, is significant in the first two specifications only.

The results for black women parallel the unadjusted results presented in Table 2. In the specifications omitting the interaction term, the checking dummy variable is significant in the first two specifications and insignificant in specifications (3) and (4). When included, employer unwillingness to hire ex-offenders exerts a positive significant effect on the outcome in all speci- 
TABLE 4

Impact of Criminal Background Checks on the Likelihood That the Most Recent Hire Is Black

\begin{tabular}{|c|c|c|c|c|c|c|c|c|}
\hline & \multicolumn{2}{|c|}{ SPECIFICATION 1} & \multicolumn{2}{|c|}{ SPECIFICATION 2} & \multicolumn{2}{|c|}{ SPECIFICATION 3} & \multicolumn{2}{|c|}{ SPECIFICATION 4} \\
\hline & (1) & (2) & (1) & (2) & (1) & (2) & (1) & (2) \\
\hline \multicolumn{9}{|l|}{ Last worker hired is a black male: } \\
\hline Checks criminal backgrounds & $.036(.012)$ & $.011(.020)$ & $.022(.013)$ & $-.003(.020)$ & $.025(.015)$ & $.004(.025)$ & $.004(.019)$ & $-.021(.028)$ \\
\hline Unwilling to hire ex-offenders & $\ldots$ & $-.046(.016)$ & $-.026(.013)$ & $-.045(.018)$ & $-.050(.015)$ & $-.065(.021)$ & $-.042(.018)$ & $-.061(.024)$ \\
\hline Checks $\times$ unwilling & & $.044(.024)$ & & $.041(.025)$ & & $.034(.031)$ & & $.042(.035)$ \\
\hline \multicolumn{9}{|c|}{ Last worker hired is a black female: } \\
\hline Checks criminal backgrounds & $.048(.012)$ & $.037(.020)$ & $.021(.013)$ & $.011(.021)$ & $.014(.015)$ & $.001(.025)$ & $-.019(.019)$ & $-.038(.027)$ \\
\hline Unwilling to hire ex-offenders & $\ldots$ & $.018(.017)$ & $.025(.013)$ & $.018(.018)$ & $.036(.016)$ & $.027(.021)$ & $.034(.018)$ & $.020(.023)$ \\
\hline Checks $\times$ unwilling & $\ldots$ & $.013(.025)$ & $\ldots$ & $.015(.026)$ & $\ldots$ & $.019(.031)$ & $\ldots$ & $.031(.034)$ \\
\hline
\end{tabular}

Note. - Values are unadjusted and regression-adjusted first-difference and difference-in-differences estimates. Standard errors are in parentheses. The remainder of the model specifications (the results of which are not reported in the table) correspond to the model specifications used in Table 3 . 
fications. In the difference-in-difference models, the coefficient on the interaction term is small and statistically insignificant in all specifications.

\section{EFFects on Other Groups OF COMMONLY Stigmatized ApPlicants}

The results in the previous section are consistent with the proposition that in the absence of a criminal background check, employers use race to infer past criminal activity, especially employers with a strong stated aversion to hiring ex-offenders. The results also suggest that the impact of such statistical discrimination on the likelihood that the most recently hired employee is black is of sufficient magnitude to swamp any negative effect of a criminal background check on black hiring rates. While in our theoretical and empirical discussion presented above we have couched the discussion of statistical discrimination in terms of employers making use of the physical markers of race to infer past criminality, the same argument can be applied to any external signal that a job applicant may convey (intentionally or unintentionally) when applying for a job. For example, employers may cue in on such signals as gaps in employment history, levels of education, or receipt of public assistance. Demonstrating empirically that the patterns observed for African Americans' hiring outcomes hold more generally for other stigmatized groups would surely buttress confidence in the empirical results presented above and the interpretation that we are offering.

In this section, we explore whether employer-initiated criminal background checks and the interaction between such checks and employer aversion to hiring ex-offenders impact employer demand for other groups of potentially stigmatized workers. While in the previous section we were able to analyze the race of the most recently hired employees (an actual outcome), here we must rely on employer responses to questions about the likelihood that they would hire applicants from a set of potentially stigmatized groups. In addition to the question concerning the likelihood that employers would hire an exoffender, employers were also queried about the likelihood that they would hire welfare recipients, workers with gaps in their employment histories, workers who have been unemployed for a year or more, and workers with a GED instead of a high school diploma. For each of these questions we coded a dummy variable equal to one if the employer responded that it would either definitely or probably hire such applicants and to zero if it probably or definitely would not hire such applicants. These dummy variables that refer to the four types of applicants are our dependent variables in this section.

Table 5 presents model results for employer willingness to hire workers for stigmatized groups. The structure of the presentation of results and the 
model specifications are identical to those for the gender-specific hiring outcomes analyzed in Table $4 .^{16}$

We begin by summarizing the model results in which the interaction term is omitted. In general, criminal background checks positively affect the likelihood that the employer indicates a willingness to hire workers from these applicant pools. These positive effects are statistically significant at reasonable levels for the outcomes for spotty work history and being unemployed for a year for specifications (1)-(3) but not for the final specification. For the welfare recipient and GED outcomes, the coefficients on background checks are small and statistically insignificant. One strong pattern in all of the models is that the dummy variable indicating that employers are unwilling to hire ex-offenders exerts strong negative and significant effects on employer willingness to hire from these specific applicant pools. ${ }^{17}$ Hence, in addition to some evidence of a positive impact of checking on employer willingness to hire applicants from stigmatized groups, the consistent negative effects of unwillingness to hire ex-offenders hint at the possibility that employers infer that these characteristics signal previous criminal activity.

Turning to the difference-in-difference models containing the interaction terms, all of the point estimates on the interaction terms are positive, which suggests that the positive effects of a criminal background check on employer willingness to hire these workers is greatest among employers that are least willing to hire ex-offenders. However, the relative effects are significant only for specifications (1) and (2) in the welfare recipient models and all specifications of the models for spotty work history. The latter results are quite strong and merit further discussion.

In all four models containing interactions terms for the spotty work history outcomes, we observe a rather strong pattern that is unaffected by the inclusion of additional control variables. First, employers that are unwilling to hire ex-offenders are considerably less likely to indicate that they are willing to hire applicants with gaps in their employment history. Second, this large negative effect of unwillingness to hire ex-offenders is countered in large part by whether such firms check criminal backgrounds. Hence, among firms that do not check criminal backgrounds, the impact of unwillingness to hire ex-offenders on the willingness to hire an applicant with a spotty work history ranges from 20 to 24 percentage points (all statistically significant at the 1 percent level of confidence). On the other hand, among firms that do check criminal backgrounds, the comparable effects of a stated unwillingness to

\footnotetext{
${ }^{16}$ The one difference between the specifications in Table 4 and Table 5 occurs in specification (4). In Table 5, specification (4), we do not control for the types of workers that an employer would be unwilling to hire since the inversely coded dummy variables for these controls are our dependent variables in this section.

${ }^{17}$ These effects are all negative and statistically significant save for the coefficient on unwilling to hire in specification (4) of the models for applicants with general equivalency diplomas.
} 
hire ex-offenders ranges from 8 to 13 percentage points. These patterns suggest a great degree of substitution between using formal criminal background checks and looking for gaps in employment history to screen out potential felons.

Note that of the four outcomes analyzed in Table 5, the outcome indicating employer willingness to hire applicants with gaps in their employment history is perhaps the one that arguably conveys the strongest signal of previous criminality. Given the strong findings for this particular outcome, and the general results for the other three outcomes, we conclude that these findings lend support to the racial hiring outcomes analyzed above.

\section{CONCLUSION}

The findings of this study are several. To begin, the empirical estimates indicate that employers who perform criminal background checks are more likely to hire black applicants than employers that do not. This positive association remains even after adjusting for an establishment's spatial proximity to black residential areas and for the proportion of applications that come from African Americans. In the context of the theoretical arguments discussed above, this positive net effect indicates that the adverse consequence of employer-initiated background checks on the likelihood of hiring African Americans is more than offset by the positive effect of eliminating statistical discrimination. To be sure, the group of workers who are excluded by a background check are surely different from the group of workers who are harmed by incorrect perceptions regarding their criminal histories. In other words, behind the net changes are two offsetting gross effects that impact the welfare of alternative groups of African American workers.

In addition, we find that the positive effect of criminal background checks on the likelihood that an employer hires a black applicant is larger among firms that are unwilling to hire ex-offenders. This pattern is consistent with the proposition that employers with a particularly strong aversion to exoffenders may be more likely to overestimate the relationship between criminality and race and hence hire too few African Americans as a result. Moreover, these relative results are observed for the likelihood that the most recent hire is a black male but not in models in which the outcome measures whether the most recent hire is a black female. Finally, the results for black hiring outcomes are generally supported by comparable results for models analyzing employer willingness to hire workers from other potentially stigmatized groups of applicants.

The results of this study suggest that curtailing access to criminal history records may actually harm more people than it helps and aggravate racial differences in labor market outcomes. Moreover, to the extent that statistical discrimination engenders an endogenous behavioral response on the part of young black men that serves to self-fulfill erroneous expectations, the long- 
TABLE 5

Impact of Criminal Background Checks on the Willingness of Employers to Hire Stigmatized Applicants

\begin{tabular}{|c|c|c|c|c|c|c|c|c|}
\hline \multirow[b]{2}{*}{ WiLLINGNESS TO HiRE } & \multicolumn{2}{|c|}{ SPECIFICATION 1} & \multicolumn{2}{|c|}{ SPECIFICATION 2} & \multicolumn{2}{|c|}{ SPECIFICATION 3} & \multicolumn{2}{|c|}{ SPECIFICATION 4} \\
\hline & (1) & (2) & (1) & (2) & (1) & (2) & (1) & (2) \\
\hline \multicolumn{9}{|l|}{ Welfare recipient: } \\
\hline Checks criminal backgrounds & $.012(.011)$ & $-.009(.018)$ & $.018(.012)$ & $-.007(.019)$ & $.021(.016)$ & $.011(.026)$ & $-.008(.018)$ & $-.006(.028)$ \\
\hline Unwilling to hire $\mathrm{e}$ & $\ldots$ & $-.117(.016)$ & $-.092(.012)$ & $-.111(.017)$ & $-.113(.016)$ & $-.120(.021)$ & $-.096(.018)$ & $-.095(.023)$ \\
\hline Checks $\times$ unwilling & & $.050(.023)$ & & $.041(.025)$ & & $.016(.032)$ & & $-.003(.035)$ \\
\hline \multicolumn{9}{|l|}{ Spotty work history: } \\
\hline Checks criminal backgrounds & $.031(.020)$ & $-.021(.032)$ & $.039(.022)$ & $-.032(.034)$ & $.041(.026)$ & $-.038(.042)$ & $-.032(.030)$ & $-.096(.046)$ \\
\hline Unwilling to hire ex-offenders & $\ldots$ & $-.242(.027)$ & $-.187(.022)$ & $-.239(.029)$ & $-.148(.026)$ & $-.202(.035)$ & $-.157(.029)$ & $-.202(.037)$ \\
\hline Checks $\times$ unwilling & $\ldots$ & $.114(.041)$ & $\ldots$ & $.114(.043)$ & & $.124(.053)$ & $\ldots$ & $.105(.056)$ \\
\hline \multicolumn{9}{|l|}{ Unemployed for a year or more: } \\
\hline Checks criminal backgrounds & $.038(.016)$ & $.021(.025)$ & $.056(.017)$ & $.034(.027)$ & $.054(.021)$ & $.042(.034)$ & $.013(.024)$ & $-.001(.037)$ \\
\hline Unwilling to hire ex-offenders & $\ldots$ & $-.140(.021)$ & $-.116(.017)$ & $-.132(.023)$ & $-.115(.021)$ & $-.123(.027)$ & $-.117(.024)$ & $-.127(.030)$ \\
\hline Checks $\times$ unwilling & . & $.048(.032)$ & & $.037(.034)$ & & $.019(.042)$ & (2) & $.023(.046)$ \\
\hline \multicolumn{9}{|l|}{ Has a general equivalency diploma: } \\
\hline Checks criminal backgrounds & $.010(.008)$ & $-.004(.012)$ & $.007(.008)$ & $-.009(.013)$ & $-.007(.009)$ & $-.025(.016)$ & $-.005(.011)$ & $-.027(.017)$ \\
\hline Unwilling to hire ex-offenders & & $-.054(.011)$ & $-.039(.008)$ & $-.051(.011)$ & $-.034(.010)$ & $-.047(.013)$ & $-.014(.010)$ & $-.029(.014)$ \\
\hline Checks $\times$ unwilling & $\ldots$ & $.029(.016)$ & $\ldots$ & $.027(.017)$ & & $.028(.020)$ & $\ldots$ & $.035(.021)$ \\
\hline
\end{tabular}

NoTE. - Values are unadjusted and regression-adjusted first-difference and difference-in-differences estimates. Standard errors are in parentheses. "Willingness to hire" indicates that an employer would definitely or probably hire an applicant with the indicated characteristic. The remainder of the model specifications (the results of which are not reported in the table) correspond to those used in Table 3. 
term consequences of such discrimination may be particularly pernicious. Surely, calls to seal criminal history records fail to take into account this unintended consequence and the market failure associated with the inferior information that employers would have as a result.

This being said, however, the prescription for greater public access to criminal history records runs into the thorny implementation problems associated with 52 nonstandardized information systems. In addition to the nontrivial likelihood of false-positive background checks, the collateral consequences of complete access to criminal history records is sure to punish many ex-offenders with relatively minor and distant run-ins with the law. Clearly, more research is needed on the effect of a criminal history record on the labor market outcomes of the ex-offender and his neighbor. In particular, more systematic research that evaluates the contribution of these factors to racial inequality is needed. 


\section{APPENDIX}

TABLE A1

Establishment Characteristics by Employer Self-Reported Likelihood of Hiring Applicants with Criminal Backgrounds

\begin{tabular}{|c|c|c|c|c|}
\hline & $\begin{array}{l}\text { Definitely } \\
\text { Will }\end{array}$ & $\begin{array}{c}\text { Probably } \\
\text { Will }\end{array}$ & $\begin{array}{c}\text { Probably } \\
\text { Not }\end{array}$ & $\begin{array}{c}\text { Definitely } \\
\text { Not }\end{array}$ \\
\hline \multicolumn{5}{|l|}{ Size: } \\
\hline$<20$ employees & .26 & .31 & .37 & .36 \\
\hline 20-99 employees & .29 & .33 & .32 & .33 \\
\hline 100-499 employees & .31 & .27 & .23 & .20 \\
\hline 500-999 employees & .06 & .04 & .04 & .03 \\
\hline $1,000+$ employees & .08 & .05 & .04 & .07 \\
\hline \multicolumn{5}{|l|}{ Industry: } \\
\hline Mining & .00 & .00 & .00 & .00 \\
\hline Construction & .02 & .03 & .03 & .01 \\
\hline Manufacturing & .32 & .29 & .18 & .12 \\
\hline Transportation, communications, and utilities & .05 & .05 & .06 & .06 \\
\hline Wholesale trade & .05 & .10 & .09 & .04 \\
\hline Retail trade & .20 & .15 & .19 & .17 \\
\hline Finance, insurance, and real estate & .02 & .05 & .11 & .16 \\
\hline Services & .30 & .31 & .32 & .36 \\
\hline Union $(\%)$ & 15.94 & 13.17 & 12.48 & 17.67 \\
\hline Central city & .33 & .27 & .27 & .28 \\
\hline Black hiring agent & .05 & .07 & .06 & .06 \\
\hline Distance black & 17.35 & 17.97 & 17.80 & 17.19 \\
\hline Distance white & 22.57 & 22.63 & 22.58 & 22.26 \\
\hline \multicolumn{5}{|l|}{ Recruitment methods used:a } \\
\hline Help-wanted signs & .31 & .28 & .24 & .27 \\
\hline Newspaper ads & .45 & .46 & .48 & .50 \\
\hline Walk-ins & .78 & .74 & 67 & .66 \\
\hline \multicolumn{5}{|l|}{ Referrals: } \\
\hline From current employees & .84 & .84 & .83 & .81 \\
\hline From state agency & .46 & .40 & .31 & .30 \\
\hline From private agency & .23 & .21 & .21 & .17 \\
\hline From community agency & .33 & .26 & .24 & .25 \\
\hline From school & .40 & .34 & .34 & .38 \\
\hline From union & .08 & .06 & .06 & .06 \\
\hline Uses affirmative action to recruit & .61 & .55 & .50 & .56 \\
\hline \multicolumn{5}{|l|}{ Screening methods: ${ }^{\mathrm{a}}$} \\
\hline Drug test/physical exam & .20 & .15 & .15 & .19 \\
\hline Aptitude test & .09 & .09 & .14 & .14 \\
\hline Knowledge test & .16 & .17 & .16 & .15 \\
\hline Personality test & .03 & .05 & .07 & .09 \\
\hline \multicolumn{5}{|l|}{ Background checks: } \\
\hline Criminal background & .39 & .45 & .47 & .67 \\
\hline Education & .66 & .69 & .68 & .70 \\
\hline References & .92 & .95 & .96 & .97 \\
\hline \multicolumn{5}{|l|}{ Daily job tasks: } \\
\hline Customer contact & .52 & .49 & .60 & .71 \\
\hline Phone conversations & .48 & .49 & .55 & .55 \\
\hline Reading & .53 & .56 & .52 & .58 \\
\hline Writing & .28 & .29 & .30 & .34 \\
\hline Math/computations & .63 & .66 & .67 & .64 \\
\hline
\end{tabular}


TABLE A1 (Continued)

\begin{tabular}{|c|c|c|c|c|}
\hline & $\begin{array}{l}\text { Definitely } \\
\text { Will }\end{array}$ & $\begin{array}{l}\text { Probably } \\
\text { Will }\end{array}$ & $\begin{array}{l}\text { Probably } \\
\text { Not }\end{array}$ & $\begin{array}{l}\text { Definitely } \\
\text { Not }\end{array}$ \\
\hline Computer work & .48 & .47 & .54 & .51 \\
\hline \multicolumn{5}{|l|}{ Job qualifications: } \\
\hline High school diploma & .57 & .68 & .74 & .79 \\
\hline Recent work experience & .63 & .68 & .70 & 69 \\
\hline Specific experience & .55 & .60 & .60 & .62 \\
\hline References & .69 & .67 & .74 & .78 \\
\hline Vocational education & .34 & .40 & .38 & .39 \\
\hline \multicolumn{5}{|l|}{$\begin{array}{l}\text { Very important requirement of new } \\
\text { employees: }\end{array}$} \\
\hline Physically attractive & .09 & .10 & .11 & .17 \\
\hline Physical neatness & .44 & .45 & .56 & .62 \\
\hline Polite & .71 & .70 & .80 & .83 \\
\hline Verbal skills & .54 & .54 & .64 & .72 \\
\hline Motivation & .71 & .70 & .76 & .76 \\
\hline Speaks English & .44 & .47 & .59 & .65 \\
\hline \multicolumn{5}{|c|}{$\begin{array}{l}\text { Type of applicants who would probably not be } \\
\text { hired: }\end{array}$} \\
\hline On welfare & .01 & .04 & .10 & .18 \\
\hline With general equivalency diploma & .01 & .02 & .03 & .11 \\
\hline Spotty work history & .21 & .36 & .51 & .46 \\
\hline Unemployed for a year & .06 & .13 & .21 & .26 \\
\hline
\end{tabular}

NoTE. - All figures are conditional averages and use sample weights. ${ }^{a}$ Variables equal one if employer reports regularly using the method. 
TABLE A2

Establishment Characteristics and Frequency with Which Employers Check the CRIMINAL BACKgrounds of APPLICANTS

\begin{tabular}{|c|c|c|c|}
\hline & Always & Sometimes & Never \\
\hline \multicolumn{4}{|l|}{ Size: } \\
\hline$<20$ employees & .24 & .28 & .38 \\
\hline 20-99 employees & .31 & .31 & .32 \\
\hline 100-499 employees & .28 & .27 & .24 \\
\hline 500-999 employees & .08 & .06 & .03 \\
\hline $1,000+$ employees & .10 & .09 & .04 \\
\hline \multicolumn{4}{|l|}{ Industry: } \\
\hline Mining & .00 & .00 & .00 \\
\hline Construction & .02 & .03 & .02 \\
\hline Manufacturing & .10 & .20 & .27 \\
\hline Transportation, communications, and utilities & .08 & .04 & .05 \\
\hline Wholesale trade & .04 & .10 & .09 \\
\hline Retail trade & .15 & .19 & .17 \\
\hline Finance, insurance, and real estate & .14 & .08 & .06 \\
\hline Services & .40 & .34 & .33 \\
\hline Union (\%) & 23.65 & 13.23 & 11.23 \\
\hline Central city & .28 & .31 & .26 \\
\hline Black hiring agent & .09 & .07 & .04 \\
\hline Distance black & 17.36 & 17.59 & 17.78 \\
\hline Distance white & 22.42 & 22.55 & 22.42 \\
\hline \multicolumn{4}{|l|}{ Recruitment methods used: ${ }^{\mathrm{a}}$} \\
\hline Help-wanted signs & .29 & .30 & .23 \\
\hline Newspaper ads & .51 & .50 & .46 \\
\hline Walk-ins & .72 & .73 & .66 \\
\hline \multicolumn{4}{|l|}{ Referrals: } \\
\hline From current employees & .85 & .85 & .80 \\
\hline From state agency & .40 & .40 & .29 \\
\hline From private agency & .22 & .23 & .20 \\
\hline From community agency & .32 & .30 & .22 \\
\hline From school & .47 & .35 & .32 \\
\hline From union & .10 & .08 & .04 \\
\hline Uses affirmative action to recruit & .69 & .57 & .48 \\
\hline \multicolumn{4}{|l|}{ Screening methods: ${ }^{\mathrm{a}}$} \\
\hline Drug test/physical exam & .24 & .18 & .11 \\
\hline Aptitude test & .15 & .13 & .10 \\
\hline Knowledge test & .18 & .18 & .15 \\
\hline Personality test & .09 & .05 & .06 \\
\hline \multicolumn{4}{|l|}{ Background checks: } \\
\hline Criminal background & 1.00 & 1.00 & .00 \\
\hline Education & .83 & .83 & .58 \\
\hline References & .98 & .98 & .93 \\
\hline \multicolumn{4}{|l|}{ Daily job tasks: } \\
\hline Customer contact & 69 & 62 & .52 \\
\hline Phone conversations & .55 & .54 & .54 \\
\hline Reading & .62 & .56 & .54 \\
\hline Writing & .38 & .29 & .34 \\
\hline Math/computations & .65 & .62 & .68 \\
\hline Computer work & .54 & .52 & .54 \\
\hline \multicolumn{4}{|l|}{ Job qualifications: } \\
\hline High school diploma & .76 & .74 & .68 \\
\hline Recent work experience & .70 & .72 & .69 \\
\hline
\end{tabular}


TABLE A2 (Continued)

\begin{tabular}{lccr}
\hline \hline & Always & Sometimes & Never \\
\hline Specific experience & .63 & .60 & .63 \\
References & .80 & .75 & .69 \\
Vocational education & .40 & .42 & .39 \\
Very important requirement of new & & & .10 \\
$\quad$ employees: & & .10 & .52 \\
Physically attractive & .14 & .54 & .77 \\
Physical neatness & .55 & .74 & .63 \\
Polite & .81 & .56 & .76 \\
Verbal skills & .70 & .73 & .56 \\
Motivation & .76 & .53 & .09 \\
Speaks English & .60 & & .04 \\
Type of applicants who would probably not be & & .07 & .43 \\
$\quad$ hired: & & .02 & .20 \\
On welfare & .09 & .41 & .16 \\
With general equivalency diploma & .04 & & \\
Spotty work history & .40 & .15 & \\
Unemployed for a year & & & \\
\hline
\end{tabular}

Note. - All figures are conditional averages and use sample weights

${ }^{\text {a }}$ Variables equal one if employer reports regularly using the method.

\section{REFERENCES}

Aigner, Dennis J., and Glen G. Cain. 1977. "Statistical Theories of Discrimination in Labor Markets." Industrial and Labor Relations Review 30: 175-87.

Altonji, Joseph G., and Charles R. Pierret. 2001. "Employer Learning and Statistical Discrimination." Quarterly Journal of Economics 116:313-50.

Autor, David H., and David Scarborough. 2004. "Will Job Testing Harm Minority Workers." Working paper. Massachusetts Institute of Technology, Cambridge.

Bates, Timothy. 1993. Banking on Black Enterprise: The Potential of Emerging Firms for Revitalizing Urban Economies. Washington, D.C.: Joint Center for Political and Economics Studies.

Bonczar, Thomas P., and Allen J. Beck. 1997. "Lifetime Likelihood of Going to State or Federal Prison." Bureau of Justice Statistics Special Report, NCJ-160092. Washington, D.C.: U.S. Department of Justice.

Bushway, Shawn D. 1998. "Labor Market Effects of Permitting Employer Access to Criminal History Records." Working paper. University of Maryland, College Park.

—_ 2004. "Labor Market Effects of Permitting Employer Access to Criminal History Records." Journal of Contemporary Criminal Justice 20: 276-91.

Carrington, William J., and Kenneth R. Troske. 1998. "Interfirm Segregation and the Black-White Wage Gap." Journal of Labor Economics 16:231-60. 
Hahn, J. M. 1991. "Pre-employment Information Services: Employers Beware." Employee Relations Law Journal 17:45-69.

Holzer, Harry J. 1996. What Employers Want: Job Prospects for Less Educated Workers. New York: Russell Sage Foundation.

Holzer, Harry J., and Keith R. Ihlanfeldt. 1996. "Spatial Factors and the Employment of Blacks at the Firm Level." New England Economic Review May/June, pp. 65-68.

— 1 1998. "Customer Discrimination and Employment Outcomes for Minority Workers." Quarterly Journal of Economics 113:835-68.

Holzer, Harry, Joleen Kirschenman, Philip Moss, and Chris Tilly. 2000. Multi-city Study of Urban Inequality, 1992-1994 (computer file). 2d ICPSR version. Ann Arbor, Mich: Inter-university Consortium for Political and Social Research (distributor).

Ihlanfeldt, Keith R., and Madelyn V. Young. 1996. "The Spatial Distribution of Black Employment between the Central City and the Suburbs." Economic Inquiry 34:693-707.

Kling, Jeffrey. 1995. "High Performance Work Systems and Firm Performance." Monthly Labor Review 118(5):29-36.

Loury, Glen C. 2002. The Anatomy of Racial Inequality. Cambridge, Mass.: Harvard University Press.

Lundberg, Shelly, and Richard Startz. 1983. "Private Discrimination and Social Intervention in Competitive Labor Markets." American Economic Review 72:340-47.

Pager, Devah. 2003. "The Mark of a Criminal Record." American Journal of Sociology 108:937-75.

Raphael, Steven, Michael Stoll, and Harry J. Holzer. 2000. “Are Suburban Firms More Likely to Discriminate against African-Americans?" Journal of Urban Economics 48:485-508.

Scott, R. Craig. 1987. "Negligent Hiring: Guilt by Association.” Personnel Administrator 32:32-34.

Stoll, Michael A., and Steven Raphael. 2000. "Racial Differences in Spatial Job Search Patterns: Exploring the Causes and Consequences." Economic Geography 76:201-23.

Turner, Susan C. 1997. "Barriers to a Better Break: Employer Discrimination and Spatial Mismatch in Metropolitan Detroit." Journal of Urban Affairs 19:123-41.

U.S. Department of Justice. 1999. Compendium of State Privacy and Security Legislation: 1999 Overview. Washington, D.C.: Department of Justice. 